\title{
THE RELATIONS BETWEEN CERTAIN MOTOR ABILITIES AND SUCCESS IN RHYTHMIC GYMNASTICS IN THE STUDENTS OF DIFFERENT GENDERS
}

\author{
Lidija Moskovljević \\ University of Belgrade, Faculty of Sport and Physical Education, Serbia
}

\begin{abstract}
The aim of this study was to examine the relations between the achievement in acquiring the program of rhythmic gymnastics (RG) and the motor abilities important for success in this sport discipline, in the students of different genders. The study included 58 Faculty of Sport and Physical Education students (29 male students and 29 female students, aged 20-21). Balance was measured using the 'Flamingo' balance test; overall coordination was mAeasured using the test of 20 lunges with a stick; coordination in rhythm using the Drumming with legs and arms test; flexibility was measured using the Active straight leg raise test; explosive muscle power of the leg extensors was measured using the Split squat vertical jump test and High jump after a dismount and repetitive muscle power of the leg extensors was measured using the test of a Series of repetitive jumps lasting 15s. The success in RG was operationalized through the expert assessment. To determine the relationship between motor abilities and expert assessment Pearson's correlation analysis was used (Pearson-product moment). The results of this research indicate the conclusion that the motor abilities i.e. flexibility and coordination are significant for successful acquisition of the program contents of RG among the students of the Faculty of Sport and Physical Education.
\end{abstract}

Key words: FLEXIBILITY / COORDINATION / ASSESSMENT / PHYSICAL EDUCATION / SPORT

\section{INTRODUCTION}

In physical culture, especially in its educational and sports entity, the integrity of students in their development and functioning has been emphasized (Ismail, 1976). In order to improve the quality of each student's specific motor activity through PE lessons, the adequate program content is necessary to be well designed and properly applied. Whether a student will be successful in performing certain motor activity depends on numerous factors. The research results have shown that, in addition to anthropometric characteristics, functional abilities and psychological characteristics, motor abilities are also important for achieving success in physical education and sport (Kasum, 2001; Karalejić, \& Jakovljević, 2008; Popović, 2010). Motor abilities are of primary importance in solving sports problems and they are a precondition for performing com- plex forms of movement. The motor abilities of an individual directly determine the success of physical activity performance (Nedeljković, 2007). The manifestation of motor abilities may be influenced by the factors such as: physical posture, gender, level of physical activities and abilities (Astran, \& Rodahl, 1986; Abernethy, Wilson et al., 1995; Keating, \& Matyas, 1996, according to Nedeljković, 2007).

When the athletes' skills and quality of performance are set as the research criterion in the science of sport, then they provide a special contribution to the sports practice. The criterion may include a set of variables-factors of success which define the success in certain sports (kinesiology and physical) activity (Jakovljević, Karalejić, \& Radovanović, 2007). Rhythmic gymnastics (hereinafter referred to as: RG) belongs to a group of sports, together with diving, figure skating, synchronized swimming and sports gymnastics, where the sports results, in addition to success, are expressed by an average mark 
given by a number of judges. The movements in rhythmic gymnastics represent a system of perfectly coordinated movements, which are willingly controlled, with a tendency to meet specific sports and aesthetic criteria when performing them. A complexity of the motion activities in rhythmic gymnastics is conditioned by the manifestation of a great number of motor abilities (Karpenko, 2003). Rhythmic gymnastics, as a sports discipline, is characterized by mastering quite complex motor movements by the body and apparatus and bringing them into a harmonious space-time relation, which requires a high degree of the gymnast's efficacy. Therefore, it is necessary that the motor abilities, required for correct and precise performance of the elements by the body, are brought to an optimum or high degree by a training process. The results of this research have shown that the determinants of success in rhythmic gymnastics are morphological, motor, psychological and musical ones. The greatest number of studies has been dealing with determining the relations between the structure of motor abilities and the success in performing the elements of rhythmic gymnastics, i.e. identifying the motor abilities significant for the successful performance of complex structural movements in RG. In these studies, as the motor abilities significant for success in RG, the following have been distinguished: flexibility, overall coordination and its factor of coordination in rhythm, precision of movements, balance, speed, power (Popović, 1986; Miletić, Srhoj, \& Bonacin, 1998; Sanader, 2000; Miletić, Sekulić, \& Wolf-Cvitak, 2004; Di Cagno et al., 2008; Moskovljević, Radisavljević, \& Dabović, 2009).

Rhythmic gymnastics, as a content of the physical education curriculum, includes a variety of movements which could influence the students' overall specificities (morpho-functional, motor, psychological, musical), since, among other things, the specificity of physical education is the development of psycho-motor abilities (Višnjić, Jovanović, \& Miletić, 2004). As a form of physical exercise it provides great possibilities of achieving the goals and tasks in physical education (Radisavljević, \& Moskovljević, 2011). The basic contents of rhythmic gymnastics, as well as all other contents of the basics of children's sports, should be implemented through the curriculum of physical education from the first grade of primary school, under the expert guidance of the sport and physical education teachers (Jevtić, Radojević, Juhas, \& Ropret, 2011).

Male students, as the future sport and physical education teachers, should be familiar with the basics of this sport and should be able to successfully convey the knowledge and skills to the children of both sexes through the physical education teaching, and in accordance with the Curriculum. It often happened that the male physical education teachers used to avoid these contents in their work with children since they were not trained to do so, and the fact is that the contents of rhythmic gymnastics are provided by the educational standards and curriculum for primary school. The scientific studies have confirmed that male students may be almost as successful as female students, in acquiring the contents of RG syllabus (Moskovljević, \& Orlić, 2012). In sports domain, there is a significant relationship between motor abilities (flexibility, balance, coordination, coordination in rhythm, explosive power) and success in RG (Popović, 1986; Miletić et al., 1998; Miletić et al., 2004; Douda, Avloniti, Kasabalis, \& Tokmakidis, 2007; Moskovljević et al., 2009). There are few previous studies including the sample of student population, especially male students, that have come to different results and they do not provide a clear picture about the relation between motor abilities and success in performing the technique of RG (Wolf-Cvitak, 1984; Šebić-Zuhrić, Manić, Bonacin, \& Hmjelovjec, 2008). For these reasons, this research examined the said motor abilities, significant for success in RG, but in the student population of both genders.

The aim of this research was to examine the relationship between the achievements in acquiring the RG syllabus and the motor abilities significant for success in RG, in the students of the Faculty of Sport and Physical Education of both genders. On the basis on the aforementioned results of the previous studies, speaking about a significant relationship between flexibility, balance, coordination, coordination in rhythm, and explosive power and the success in RG as a sports branch, it has been assumed that the sample of the students of the Faculty of Sport and Physical Education of both genders will show a significant relationship between motor abilities and success in acquiring the RG contents. 


\section{METHOD}

\section{Participants}

The study included 58 students of the second year of academic studies at the faculty of Sport and Physical Education, aged 20-21. According to the gender, the sample included 29 male students and 29 female students. Such a sample was selected bearing in mind that the contents of RG are provided by the educational standards and curriculum for primary school and that the students of the Faculty of Sport and Physical Education as the future teachers of sport and physical education have to acquire the knowledge and skills of RG, regardless of the gender.

\section{Variables and Instruments}

The assessment of motor status of the subjects was performed on the basis of the data obtained using the tests assessing balance, coordination, flexibility, explosive and repetitive muscle power of the leg extensors. The success in RG was operationalized through the expert assessment.

To assess balance of the entire body, the 'Flamingo' balance test was used (Eurofit, 1993). The test is performed on a balance beam, by standing on a single leg.

To assess overall coordination, the test of 20 lunges with a stick was used (Kurelić, Momirović, Stojanović, Šturm, Radojević, \& Viskić, 1975). The subjects' task was to regularly step forward 20 times first with their right leg, then with their left leg, pulling the stick under their leg with each lunge.

To assess coordination in rhythm the test of rhythmical drumming with legs and arms was used (Metikoš, Hofman, Prot, Pintar, \& Oreb, 1989). This test consists of the cycles of alternating movements of legs and arms for a certain period of time.

To assess flexibility the test of Active straight leg raise was used (Božić, Pažin, Berjan, Planić, \& Ćuk, 2010). This test assesses active flexibility (a subject actively raises one leg until reaching the maximum amplitude) and passive flexibility (the examiner additionally pushes the leg to the final amplitude) of the hamstring thigh muscles.

To assess the repetitive leg muscle power the test of a series of repetitive jumps lasting 15s (15sSPSkok) was performed using the Optojump-computerized system Bosco (Bosco, \& Luhtanen, 1983). The sub- jects, within a specified time interval, perform the maximum number of high jumps possible, with the contact time as short as possible.

In order to assess the explosive leg muscle power the two tests were used, also using the Optojump-computerized system Bosco, i.e. split squat vertical jump with no arm swing - SkokVPČ (Komi, \& Bosco, 1978) and high jump after a dismount with no arm swing (SkokVNS), which measures the maximum height of the jump and explosive power as well.

To assess the success of performance in RG the expert assessment was used. The composition without any apparatus, the composition with a rope and the composition with a ball were evaluated based on a video recording. The three international female judges holding a valid „Brevet" licence of the International Gymnastic Federation in rhythmic gymnastics, assessed the recorded compositions, independently. For each composition, each judge gave three marks: a mark for the accuracy of a composition, a mark for a technique of the composition performance, and a mark for the harmonization of the movements with the music. Out of these three marks, an average mark for each composition was derived. Afterwards, an average mark for all the three compositions was derived. The final expert mark was derived as a mean value of the three judges' marks.

Before they started assessing the subjects, the judges were completely informed by the authors of this research about the compositions to be evaluated and the entire evaluation procedure as well. It should be noted that the students' evaluation criteria, within the Theory and Teaching methods of RG course at the Faculty of Sport and Physical Education, are different from the assessment of female competitors. In the case of the students, the priority is given to the correct, precise and harmonious performance of the compositions, where it is not insisted on great amplitudes. The assessment, due to the criterion of harmonization, was carried out according to the Scale for assessing the acquisition of the program contents of rhythmic gymnastics (Table 1), with the same assessment criterion for both male and female subjects, and in accordance with the parts of the Rulebook of the International Gymnastic Federation (Rulebook of Rhythmic Gymnastics - FIG, 2013), which refer to the assessment of faults in performing the compositions and the harmonization of music and movements. The range of marks was between 5 and 10 . 
Table 1. Scale for assessing the acquisition of the program contents of rhythmic gymnastics

Mark
The composition is not performed at all or the composition is partially performed (only certain elements,
without connection), with a great number of technical faults in performance of the movements of the body and
by the apparatus, without harmonization with the music.
A small part of the composition is connected, or the entire composition is performed with many large faults in the
technique of performing the movements of the body or by the apparatus, without harmonization with the music.
The composition is entirely connected, with 3-4 incorrectly performed elements, with large and medium faults
in the technique of performing the movements of the body or by the apparatus, the movement is partially
harmonized with the music (4 and more beats).
The composition is entirely connected, with 1-2 incorrectly performed elements, with medium and small faults
in the technique of performing the movements of the body or by the apparatus, the movement is partially
harmonized with the music (4 and more beats).
The entire composition is performed correctly, with a greater number of medium and small faults in performing
the entire composition, partially harmonized with the music (up to 2 beats).
The entire composition is performed correctly, with a small number of medium and small faults in performing
certain parts of the composition, partially harmonized with the music (up to 2 beats).
The entire composition is performed correctly, with a greater number of small faults, harmonized with the music.
The entire composition is performed correctly, with the occasional small faults in performance, harmonized
with the music.
The entire composition is performed correctly, with the good technique of performing the movements of
the body and by the apparatus (possible occurrence of small faults, up to 5), with the harmonization of the
performance and complete harmony between the movements and the music.
The entire composition is performed correctly, with the good technique of performing the movements of
the body and by the apparatus (possible occurrence of 1-2 small faults), with the presence of harmony and
harmonization of the performance and complete harmony between the movements and the music.

\section{Research Course and Procedures}

All the data were collected after the completion of the course of Theory and Teaching methods of RG, which lasted for 12 weeks. The measurements were carried out in two days. On the first day, the students' motor abilities were assessed, and on the second day the students performed the compositions without apparatus, and the compositions with a rope and a ball, which were recorded by a video camera. The same examiners and judges carried out all the measurements and assessments.

\section{Statistical Procedures}

In the field of descriptive statistics the following were determined: arithmetic mean (AS), standard de- viation (SD), minimum (MIN) and maximum value (MAX). In order to determine the relationships between motor abilities and expert assessment Pearson's correlation analysis (Pearson-product moment) was used.

\section{RESULTS}

The results of descriptive statistics are shown in the Table 2. The results have shown that the average mark for all the three compositions in the male subjects was $7.53(\mathrm{SD}=0.68)$, and in the female subjects it was $7.75(\mathrm{SD}=0.81)$.

Table 2. Descriptive statistics - motor variables

\begin{tabular}{lcccccccc}
\hline & \multicolumn{4}{c}{ Male $(\mathbf{N}=\mathbf{2 9})$} & \multicolumn{5}{c}{ Female (N=29) } \\
\cline { 2 - 9 } & AS & SD & MIN & MAX & AS & SD & MIN & MAX \\
\hline Flamingo balance test & 5.45 & 4.32 & 1.00 & 17.00 & 5.55 & 3.92 & 1.00 & 14.00 \\
20 steps forward with a stick & 11.64 & 1.72 & 9.22 & 15.69 & 12.54 & 1.46 & 10.42 & 15.21 \\
Drumming with legs and arms & 12.85 & 2.87 & 7.00 & 17.75 & 12.16 & 2.28 & 5.00 & 17.00 \\
Active straight left leg raise & 96.07 & 10.55 & 76.00 & 127.00 & 108.86 & 15.03 & 71.00 & 142.00 \\
Passive straight left leg raise & 118.38 & 13.08 & 96.00 & 150.00 & 133.97 & 18.81 & 94.00 & 180.00 \\
Active straight right leg raise & 95.72 & 9.91 & 76.00 & 118.00 & 107.55 & 15.41 & 76.00 & 147.00 \\
Passive straight right leg raise & 115.69 & 11.92 & 94.00 & 144.00 & 132.45 & 19.89 & 93.00 & 180.00 \\
\hline
\end{tabular}


The relationship between the achievements in RG and the examined motor abilities in the male and female subjects was checked using the correlation analysis (Pearson's coefficient of correlation). Correlation analysis between the expert assessment of RG and the examined motor abilities obtained in the final measurement, in the entire sample, has shown that there were statistically significant correlations in the tests of 20 lunges with a stick, active straight left leg raise, passive straight left leg raise, active straight right leg raise and passive straight right leg raise (Table 3 ). In the subsample of male subjects, there was also a statistically significant correlation between the mark in RG and the score achieved in the test of drumming with legs and arms. If the subsample of female subjects is regarded, the correlations between the mark in RG and the tests of 20 lunges with a stick and drumming with legs and arms were not statistically significant.

Table 3. Pearson's correlation coefficients between motor variables and expert assessment of RG

\begin{tabular}{lccc}
\hline & Entire sample & Male & Female \\
\hline Flamingo balance test & -.232 & -.339 & -.145 \\
20 lunges with a stick & $-.286^{*}$ & $-.427^{*}$ & -.271 \\
Drumming with legs and arms & .234 & $.398^{*}$ & .122 \\
Active straight left leg raise & $.320^{*}$ & .353 & .250 \\
Passive straight left leg raise & $.409^{* *}$ & $.413^{*}$ & $.375^{*}$ \\
Active straight right leg raise & $.329^{*}$ & .302 & .299 \\
Passive straight right leg raise & $.462^{* *}$ & $.522^{* *}$ & $.421^{*}$ \\
\hline
\end{tabular}

* - significance at the level of $0.05^{* *}$ - significance at the level of 0.01

The correlation analysis between the expert assessment of RG and the results of the measurement of explosive and repetitive muscle power of the leg ex- tensors (jumps) has not shown any statistically significant correlations neither in the entire sample nor in the subsamples of male and female subjects (Table 4).

Table 4. Pearson's correlation coefficients between jumps and expert assessment of RG

\begin{tabular}{lccc}
\hline & Entire sample & Male & Female \\
\hline SkokVPČ maxcm & -.002 & .213 & .121 \\
SkokVNS maxcm & -.045 & .028 & .054 \\
SkokVNS maxWkg & .106 & .069 & .244 \\
15sSPSkok maxcm & -.002 & .051 & .139 \\
15sSPSkok maxWkg & .169 & .069 & .321 \\
\hline
\end{tabular}

\section{DISCUSSION}

The correlation analysis between the expert assessment of RG and balance, as a motor variable, has not shown any statistically significant correlations in the entire sample nor in the subsamples of male and female subjects. The influence of the ability to maintain balance was not statistically significant for the success of the performance of gymnastic compositions, a finding which is consistent with the previous research (Miletić et al., 1998; Šebić-Zuhrić et al., 2008). The reason for this may be found in the structure of a rhythmic composition itself, where the simplest exercises belonging to this structural group appeared as balance in the minimum number (1-2 balance per a composition). The positions with a greater support surface, shorter time of duration and a simpler position of free body parts were used and in such a range they did not affect the judges' assessment, and therefore they were not related to the predictor variables.

Based on the research on this issue in sport in the RG contestants (Popović, 1986; Sanader, 2000; Moskovljević et al., 2009), a positive correlation between coordination and success in RG was determined. The results of the research in the student population have not shown any correlation between the specific movements in RG and the variable of coordination (ŠebićZuhrić et al., 2008), which the authors explained by the inadequate selection of the coordination assessment tests. However, this research has confirmed a statistically significant correlation between the overall coordination and the expert assessment of RG, observed in 
the entire sample, which means that the influence of the overall coordination ability proved significant for successful acquisition of the contents of RG syllabus. General findings, obtained in the entire sample, indicate that the mentioned test of 20 lunges with a stick may be used for assessing the overall coordination, in the student population in the RG teaching.

Both overall coordination and its factor of coordination in rhythm as motor variables have shown a statistically significant positive correlation with the expert assessment of RG in the male sample, whereas in the female sample this correlation was not statistically significant. This could be explained in the following way: women mostly prefer (Gošnik, Sedar, \& Bunjevac, 2007) and practice, in their free time, physical activities which are more complex in coordination and contain aesthetic components (dance, aerobics, fitness); compared to men, therefore, they are more oriented towards the movements more complex in coordination with the emphasized aesthetic component. In this study, the male subjects showed better results when it came to the coordination (overall and its factor of coordination in rhythm) as a motor ability and they had no previous experience in the movements which are more complex in coordination with the emphasized aesthetic component, which leaves more space for improvement through the acquisition of the program contents of rhythmic gymnastics.

In all the previous studies which determined the relationship between motor abilities and successful performance in RG, the tests for assessing flexibility as a motor ability were used (Popović, 1986; Damjanovska, 1988; 2000; Miletić et al., 1998; Sanader, 2000; Bijelić, 2003; Di Cagno, et al., 2009; Moskovljević et al., 2009) which is said to be "the first among the equal“ in RG. In this research, active and passive flexibility of the left and right leg, in the subjects of both genders, were assessed. The relationship between the expert assessment in RG and all four flexibility tests was determined by the correlation analysis in the entire sample. This would mean that flexibility is extremely significant motor ability for successful acquisition of the program contents of rhythmic gymnastics as well as other related disciplines (dance, ballet), which is consistent with the previous studies (Popović, 1986; Damjanovska, 1988; 2000; Miletić et al., 1998; Moskovljević et al., 2009; Vlašić, Oreb, \& Furjan-Mandić, 2007; Sanader, 1985; Bijelić, 2003; Suzović, \& Porčić, 2012). When the relation according to the gender is observed, passive flexibility of the left and right leg showed a statistically significant correlation with the expert assessment both in male and female subjects. The possession of good passive flexibility is a precondition for achieving better results in the active flexibility. The contents of RG, practiced by the students three times a week in the practical classes, included calisthenics, elements of jumps, balance and rotations, where it was insisted on the amplitude and width of movements.

The correlation analysis determined that there was not a statistically significant correlation between the expert assessment of RG and explosive and repetitive leg muscle power, neither in the entire sample, nor in the subsamples of males and females, which is contrary to some previous studies (Wolf-Cvitak, 1984; Miletić et al., 1998). The results of this research indicate that these two motor abilities were not significant for the successful acquisition of the program contents of RG, in this case. The reason for this might be found in the fact that the duration of the rhythmic compositions, by which the successful performance was assessed, ranged between $162 / 4$ or $3 / 4$ beats. A short duration of the compositions did not allow the occurrence of a greater number of the elements belonging to one structural group (e.g. jumps), thus, within such a range (1 jump per a composition), the elements of the same structural group did not affect the expert assessment, so that a correlation with the predictor variables was not statistically significant.

The fact that the students of the Faculty of Sport and Physical Education of different genders were included in the sample of subjects may suggest a limitation of this research, thus, the results of this study cannot be generalized in the population engaged in RG. However, in the hypothesis of this research, the question was whether a correlation between the motor abilities significant for RG and the successful performance in RG would be determined in the students of the Faculty of Sport and Physical Education of both genders. The results of this research have confirmed the fact that flexibility and coordination are the two motor abilities which are the most important for successful acquisition of the program contents of RG also in the students of the Faculty of Sport and Physical Education. On the other hand, the fact significant for the sample selection is that they, as the future sport and physical education teachers, should systematically, through physical education teaching, apply the basic contents of RG to the school children of both genders. At the same time, they must know which motor abilities could be primarily developed using the contents of RG in accordance with the children's age. 


\section{CONCLUSION}

The results of this research suggest the conclusion that, in the students of the Faculty of Sport and Physical Education, the future teachers of sport and physical education, the motor abilities of coordination and flexibility, which emerged as the most important motor abilities also in the studies in the sample of the girls actively engaged in RG, are significant for the successful acquisition of the program contents of RG. The gender specificities, in favour of the male students, have been expressed in terms of the relationship between these motor abilities and the expert assessment, which should be further examined in the future. Balance, explosive and repetitive leg muscle power did not emerge as a significant factor for the successful acquisition of the contents of RG, i.e. these motor abilities did not show a significant correlation with the expert assessment of RG. In the future research, the attention should be directed towards making balance positions more complex as well as

\section{REFERENCES}

1. Bijelić, S. (2003). Baletska priprema u funkciji razvijanja motoričkih sposobnosti [Ballet preparation as a method to develop motor abilities. In Serbian]. (Unpublished doctoral dissertation). Fakultet fizičkog vaspitanja i sporta Univerzitet u Banjaluci.

2. Bosco, C., \& Luhtanen, P. (1983). A simple method for measurement of mechanical power in jumping. Eur Journal Appl Occup Physiol. 50 (2), 273-282.

3. Božić, P., Pažin, N., Berjan, B., Planić, N., \& Ćuk, I. (2010). Evaluation of the Field Tests of Flexibility of the Lower Extremity: Reliability and the Concurrent and Factorial Validity. Journal of Strength and Conditioning Research, 24(9), 2523-2531.

4. Damjanovska, M. (1988). Uticaj antropometrijskih i biomotoričkih varijabli i mogućnosti predviđanja uspeha u ritmičko-sportskoj gimnastici [Influence of antropomethic and biomotor variables and possibility to predict success in sports gymnastics. In Serbian-Croatian]. (Unpublished master thesis). Fakultet fizičke kulture, Beograd.

5. Damjanovska, M. (2000). Efektite od odredena programa ritmička gimnastika za transformacija na odredeni morfološki karakteristiki, motor i ritmička učenici veštini na osnovno učilište vo Skopje [Effe- increasing their number and the number of jumps in the gymnastic compositions in the physical exercise by the school population and the students of the Faculty of Sport and Physical Education, and finding the adequate motor tests which would in a more specific way measure the ability of maintaining balance position and the ability of explosive and repetitive leg muscle power in rhythmic gymnastics.

In the future studies, the motor factors for the successful acquisition of rhythmic gymnastics should be examined in a greater sample of the students of the Faculty of Sport and Physical Education, and the pupils of primary schools, by the implementation of the rhythmic gymnastics syllabus and introduction of the specific tests for measuring the motor abilities significant for the success in rhythmic gymnastics.

This paper is a part of the project "The Effects of the Applied Physical Activity on Locomotor, Metabolic, Psychosocial and Educational Status of the Population of the Republic of Serbia" (no. III47015).

cts of certain rhythmic gymnastics programs on transformation of certain morphological characteristics, motor and rhythmical abilities of 4-graders of elementary schools in Skopje. In Macedonian]. (Unpublished doctoral dissertation). Fakultet za fizičku kulturu, Skopje.

6. Di Cagno, A., Baldari, C., Battaglia, C., Brasili, P., Merni, F., Piazza, M., Toselli, S., Ventrella, A.R., \& Guidetti, L. (2008). Leaping ability and body composition in rhythmic gymnasts for talent identification. Journal of Sports Medicine and Physical Fitness, 48, 341-346.

7. Di Cagno, A., Baldari, C., Battaglia, C., Monteiro, M.D., Pappalardo, A., Piazza, M., \& Guidetti, L. (2009). Factors influencing performance of competitive and amateur rhythmic gymnastics - Gender differences. Journal of Science and Medicine in Sport, 12, 411-416.

8. Douda, H., Avloniti, A., Kasabalis, A., \& Tokmakidis, S. (2007). Adaptations on Physical Performance Characteristics after a 6-month specific training in rhythmic gymnasts. Medical Problems of Performing Artistis, 22, 10-17.

9. Eurofit (1993). Eurofit Tests of Physical Fitness. 2nd Edition. Strasbourg. 
10. Gošnik, J., Sedar, M., \& Bunjevac, T. (2007). Preferencije studenata/ica Filozofskog fakulteta u Zagrebu prema sportskim aktivnostima [Preferences of students of Faculty of Philosophy in Zagreb towards sports activities. In Croatian] 16. Summer School of the Croatian Kinesiologists.

11. Ismail, A.H. (1976). Integrirani razvoj: Teorija i eksperimentalni rezultati [Integrated development: Theory and experimental results. In Croatian-Serbian]. Kineziologija, 6(1-2), 7-28.

12. Jakovljević S., Karalejić, M., \& Radovanović, I. (2007). The relations between two ways of evaluation of actual individual qualities of basketball players as a criterion of their successfulness. Fizička kultura, 61 (1-2), 34-42.

13. Jevtić, B., Radojević, J., Juhas, I., \& Ropret, R. (2011). Dečiji sport od prakse do akademske oblasti [Children sport from practice to academic field. In Serbian]. Beograd: Fakultet sporta i fizičkog vaspitanja.

14. Karalejić, M., \& Jakovljević, S. (2008). Teorija $i$ metodika košarke [Theory and Teaching Methods of Basketball. In Serbian]. Beograd: Fakultet sporta i fizičkog vaspitanja.

15. Karpenko, L.A. (2003). Hudožestvennia gimnastika [Rhythmic gimnastics. In Russian] Sankt-Peterburgska Gosudarstvennia Akademia fizičeskoi kultuы imeni P.F.Lesgafta.

16. Kasum, G. (2001). Uticaj morfoloških i motoričkih karakteristika studenata FFK u Beogradu na efikasnost savladavanja programa iz rvanja [Influence of morphological and motor features of the Belgrade Faculty of Physical Culture students on efficiency of mastering wrestling syllabus. In Serbian]. Fizička kultura, 55 (1-4), 42-48.

17. Komi, P.V., \& Bosco, C. (1978). Utilization of stored elastic energy in leg extensor muscles by men and women. Medicine \& Science in Sports \& Exercise, 10, 261-265.

18. Kurelić, N., Momirović, K., Stojanović, M., Šturm, J., Radojević, Đ., \& Viskić, N. (1975). Struktura i razvoj morfoloških i motoričkih dimenzija omladine [Structure and development of morphological and motor dimensions in youth. In Serbian-Croatian]. Institut za naučna istraživanja Fakulteta za fizičko vaspitanje, Beograd.

19. Metikoš, D., Hofman, E., Prot, F., Pintar, Ž., \& Oreb, G. (1989). Mjerenje bazičnih motoričkih dimenzija sportaša [Measurement of basic motor dimensions of athletes. In Croatian-Serbian].
Zagreb: Fakultet za fizičku kulturu Sveučilišta u Zagrebu.

20. Miletić, Đ., Srhoj, Lj., \& Bonacin, D. (1998). Utjecaj inicijalnog statusa motoričkih sposobnosti na učenje motoričkih znanja u ritmičko-sportskoj gimnastici [Influence of initial status of motor abilities on learning of motor knowledge in rhytmic - sports gymnastics. In Croatian]. Kineziologija, 30(2), 66-75.

21. Miletić, Đ., Sekulić, D., \& Wolf-Cvitak, J. (2004). The leaping performance of 7-year-old novice rhythmic gymnasts is highly influenced by the condition of their motor abilities. Kinesiology, 36(1), 35-43.

22. Moskovljević, L., Radisavljević, L., \& Dabović, M. (2009). Relation Between Motor Abilities and performing of Fundamental Elements in Rhythmic Gymnastics. Proceedings FISU Conference $25^{\text {th }}$ Universiade "The role of University sports in education and society - a platform for change", (pp. 196-204). Faculty of sport and physical education, Belgrade.

23. Moskovljević, L., \& Orlić, A. (2012). Relations between abilities and attitudes of students and success in rhythmic gymnastics. Physical culture, 66(2), 129-137.

24. Nedeljković, A. (2007). Uticaj telesnih dimenzija na ispoljavanje maksimalne snagemišića [Effect of physical dimensions on manifestation of maximal muscle strength. In Serbian] (Unpublished doctoral dissertation). Fakultet sporta i fizičkog vaspitanja, Beograd.

25. Popović, R. (1986). Značaj morfoloških karakteristika, motoričkih dimenzija, muzikalnosti i nekih konativnih osobina ličnosti za uspeh u ritmičkoj gimnastici [Importance of morphological characteristics, motor dimensions and some conative personality features on success in rhytmic gymnastics. In Serbian] (Unpublished doctoral dissertation). Fakultet za fizičku kulturu, Beograd.

26. Popović, B. (2010). Effect of morphological and motor characteristics of the Belgrade Physical Culture students on efficiency of mastering judo syllabus. Physical culture, 64(1), 62-71.

27. Pravilnik ritmičke gimnastike FIG (2013). Medunarodna gimnastička federacija -FIG, Tehnički komitet za ritmičku gimnastiku FIG [FIG Technical Committee for Rhytmic Gymnastics. In Serbian]. Gimnastički savez Srbije, Savez za ritmičku gimnastiku Srbije. 
28. Radisavljević, L., \& Moskovljević, L. (2011). Osnove ritmike [Basis of Rhythmic. In Serbian]. In Jevtić et al., (eds.) Dečiji sport - od prakse do akademske oblasti [Children sport - from practice to academic field. In Serbian], (pp. 395-409). Fakultet sporta i fizičkog vaspitanja Univerzitet u Beogradu.

29. Sanader, A. (1985). Uticaj vežbi klasičnog baleta na efikasnost savladivanja osnovne tehnike u ritmičko sportskoj gimnastici [Effect of classic ballet on efficiency of mastering basic techniques in rhythmic sports gymnastics. In Serbain]. (Unpublished beachler thesis). Fakultet fizičke kulture Univerzitet u Beogradu.

30. Sanader, A. (2000). Modelne karakteristike jugoslovenskih seniorki u ritmičkoj gimnastici [Model features of Yugoslav rhytmic gymnastics senior. In Serbain]. (Unpublished master thesis). Fakultet fizičke kulture, Beograd.

31. Suzović, D., \& Porčić, B. (2012). Influence of morphological and motor features on selection in ballet. Physical culture, 66(1), 32-39.

32. Šebić Zuhrić, L., Manić, G., Bonacin, D., \& Hmjelovjec, I. (2008). Relacije bazično motoričkih sposobnosti I stilizovanih kretnih struktura u muškoj ritmičkoj gimnastici [Relations of basic motor abilities and stylized movement structures in male rhytmic gymnastics. In Serbian]. Homo Sporticus 1, 18-21.

33. Višnjić, D., Jovanović, A., \& Miletić, K. (2004). Teorija $i$ metodika fizičkog vaspitanja [Theory and teaching methods of physical education. In Serbain]. Beograd: SIA.

34. Vlašić, J., Oreb, G., \& Furjan-Mandić, G. (2007). Povezanost motoričkih i morfoloških obilježja studentica $s$ uspješnosti $u$ narodnim plesovima [Connection of motor and morphological features of female students with achievements in fold dances. In Croatian]. Kineziologija 39(1), 49-61.

35. Wolf-Cvitak, J. (1984). Relacije izmedu morfoloških i primarnih motoričkih dimenzija sa uspješnosti u ritmičko sportskoj gimnastici kod selekcioniranog uzorka ispitanika [Relations between morphological and primary motor dimensions with achievements in rhytmic-sports gymnastics in a selected sample of respondents. In Croatian-Serbian]. (Unpublished master thesis). Fakultet za fizičku kulturu, Zagreb.

\title{
RELATIONEN EINIGER MOTORISCHER FÄHIGKEITEN UND DES ERFOLGS IN RHYTHMISCHER GYMNASTIK BEI STUDENTEN UNTERSCHIEDLICHEN GESCHLECHTS
}

\begin{abstract}
Zusammenfassung:
Ziel der Untersuchung war es, bei Studenten unterschiedlichen Geschlechts die Verbindung zwischen Bewältigung eines Rhythmikgymnastik-Programms (RG) und der motorischen Fähigkeiten festzustellen, die für den Erfolg in dieser Sportdisziplin bedeutend sind. Die Untersuchung umfasste 58 StudentInnen der Fakultät für Sport und Sportunterricht (29 Studenten und 29 Studentinnen im Alter von 20-21 Jahren). Gleichgewicht wurde mit Hilfe des „Flamingo“-Tests gemessen; allgemeine Koordinierung mit Hilfe eines Tests mit 20 Schritten mit Turnkeule; Rhythmuskoordinierung mit Hilfe von Trommeln mit Beinen und Armen; Geschmeidigkeit wurde mit dem Test der aktiven Beinhebung gemessen; explosive Muskelkraft der Beinstrecker mit Hilfe eines Vertikalsprungs aus der Halbhocke und eines Strecksprungs; die Wiederholungskraft der Muskeln der Beinstrecker mit Hilfe einer Serie wiederholter Sprünge in der Dauer von 15 Sekunden. Der Erfolg in Rhythmikgymnastik-Programm wurde durch eine Experteneinschätzung operationalisiert. Für die Feststellung der Relationen zwischen den motorischen Fähigkeiten und der Experteneinschätzung wurde die Pearson-product moment Analyse verwendet. Die Ergebnisse dieser Untersuchung weisen auf die Schlussfolgerung hin, dass bei den StudentInnen der Fakultät für Sport und Sportunterricht für eine erfolgreiche Bewältigung der Inhalte eines Rhythmikgymnastik-Programms motorische Fähigkeiten, Koordinierung und Geschmeidigkeit bedeutend sind.
\end{abstract}

Schlüsselwörter: GESCHMEIDIGKEIT / KOORDINIERUNG / BEWERTUNG / SPORTUNTERRICHT / SPORT

Received: 05.07.2016.

Accepted: 02.11.2016.

(c) 2016 The Author. Published by Physical Culture (www.fizickakultura.com). This article is an open access article distributed under the terms and conditions of the Creative Commons Attribution license (http://creativecommons. org/licenses/by/3.0/rs/). 


\title{
РЕЛАЦИЈЕ НЕКИХ МОТОРИЧКИХ СПОСОБНОСТИ И УСПЕШНОСТИ У РИТМИЧКОЈ ГИМНАСТИЦИ КОД СТУДЕНАТА РАЗЛИЧИТОГ ПОЛА
}

\author{
Лидија Московљевић \\ Факултет спорта и физичког васпитања, Универзитет у Београду
}

\begin{abstract}
Сажетак
Циљ истраживања је био да се испита повезаност постигнућа у савладавању програма ритмичке гимнастике (РГ) и моторичких способности важних за успешност у овој спортској дициплини, код студената различитог пола. Истраживањем је обухваћено 58 студената Факултета спорта и физичког васпитања (29 студената и 29 студенткиња, старости 20-21 година). Равнотежа је мерена тестом „Фламинго“;општа координација, тестом 20 искорака са палицом; координација у ритму, тестом Бубњање ногама и рукама; гипкост је мерена тестом Активно подизање ноге; експлозивна снага мишића опружача ногу тестовима Вертикални скок из получучња и Скок увис након саскока и репетитивна снага мишића опружача ногу, тестом Серија поновљених скокова у трајању 15 с. Успешност у РГ је операционализована преко експертске оцене. За утврђивање везе између моторичких способности и експертске оцене коришћена је Пирсонова корелациона анализа (Pearson-product moment). Резултати овог истраживања упућују на закључак да су, код студената ФСФВ, за успешно савладавање програмских садржаја РГ посебно се издвајају моторичке способности координација и
\end{abstract}

Кључне речи: ГИПКОСТ / КООРДИНАЦИЈА / ОЦЕНА / ФИЗИЧКО ВАСПИТАҢЕ / СПОРТ

\section{УВОД}

У физичкој култури, а нарочито у њеном васпитно-образовном и спортском ентитету, истиче се интегралност ученика у његовом развоју и функционисању (Исмаил, 1976). Да би се кроз час физичког васпитања побољшао квалитет сваког ученика у одређеној моторичкој активности, неопходно је да се добро осмисли и правилно примени одговарајући програмски садржај. Да ли ће ученик бити успешан у извођењу одређене моторичке активности, зависи од многобројних фактора. Резултати истраживања показују да су поред антропометријских, функционалних способности и психолошких карактеристика, за постизање успеха у физичком васпитању и спорту од значаја и моторичке способности (Касум, 2001; Каралејић и Јаковљевић, 2008; Поповић, 2010). Моторичке способности имају примарни значај у решавању спортских задатака и услов су за из- вођење комплексних облика кретања. Моторичке способности појединца директно одређују успешност вршења физичких активности (Недељковић, 2007). Испољавање моторичких способности може бити под утицајем фактора као што су: телесни састав, пол, ниво физичких активности и способности (Astran, \& Rodahl, 1986; Abernethy, Wilson et al., 1995; Keating, \& Matyas, 1996, према Недељковић, 2007).

Када се вештина и квалитет наступа спортисте, поставе као критеријум истраживања у спортској науци, онда они дају посебан допринос спортској пракси. Под критеријумом се може подразумевати скуп варијабли-фактора успешности, са којима се дефинише успех у некој спортској (кинезиолошкој или физичкој) активности (Јаковљевић, Каралејић, и Радовановић, 2007). Ритмичка гимнастика ( у даљем тексту РГ) припада групи спортова, заједно са скоковима у воду, уметничким клизањем, синхроним пливањем и 
спортском гимнастиком, у којима се такмичарски резултат, а самим тим и успешност, изражава просечном оценом коју даје одређени број судија. Кретања у ритмичкој гимнастици представљају систем савршено координисаних покрета, вољно контролисаних, при чијем извођењу се тежи испуњавању спортско-естетских критеријума. Комплексност кретних активности у ритмичкој гимнастици, условљена је испољавањем великог броја моторичких способности (Карпенко, 2003). Ритмичку гимнастику, као спортску дисциплину, карактерише савладавање веома сложених моторичких кретања телом и реквизитом и довођење истих у складан просторно-временски однос, што захтева висок степен ефикасности гимнастичарке. Зато је потребно да моторичке способности, неопходне за правилно и прецизно извођење елемената телом, буду тренажним процесом доведене до оптималног или високог нивоа. Резултати истраживања показују да су детерминанте успешности у ритмичкој гимнастици: морфолошке, моторичке, психолошке и музичке. Највећи број истраживања односио се на утврђивање релација између структуре моторичких способности и успеха у извођењу елемената ритмичке гимнастике, односно идентификације моторичких способности које су значајне за успешно извођење сложених структурних кретања у РГ. У тим истраживањима, као значајне моторичке способности за успешност у РГ, издвојиле су се: гипкост, општа координација и њен фактор координација у ритму, прецизност покрета, равнотежа, брзина, снага (Поповић, 1986; Miletić, Srhoj, i Bonacin, 1998; Санадер, 2000; Miletić, Sekulić, i Wolf-Cvitak, 2004; Di Cagno et al., 2008; Moskovljević, Radisavljević, i Dabović, 2009).

Ритмичка гимнастика, као наставни садржај физичког васпитања, подразумева разноврсна кретања којима би се могло утицати на укупне специфичности ученика (морфо-функционалне, моторичке, психолошке, музичке), јер између осталог, специфичност физичког васпитања јесте и развој психомоторних способности (Вишњић, Јовановић, и Милетић, 2004). Као вид телесног вежठања пружа велике могућности за остваривање циљева и задатака у физичком васпитању (Радисављевић, и Московљевић, 2011). Основне садржаје ритмичке гимнастике, као и све друге садржаје из основа дечијег спорта, требало би примењивати кроз план и програм физичког васпитања од првог разреда основне школе, под стручним вођством професора спорта и физичког васпитања (Јевтић, Радојевић, Јухас, и Ропрет, 2011).

Студенти мушког пола би као будући професори спорта и физичког васпитања, требало да буду упознати са основама овог спорта и да та знања, умења и вештине могу успешно да пренесу деци оба пола кроз наставу физичког васпитања, а у складу са Наставним планом и програмом. Неретко се дешавало да професори физичког васпитања мушког пола, избегавају ове садржаје у раду са децом, јер нису били обучени за то, а чињеница је да су образовним стандардима и наставним планом за основну школу предвиђени садржаји из ритмичке гимнастике. Научна истраживања потврђују да студенти мушког пола могу бити готово подједнако успешни, као и студенти женског пола, у савладавању програмских садржаја РГ (Московљевић, и Орлић, 2012). У домену спорта, постоји значајна повезаност између моторичких способности (гипкост, равнотежа, координација, координација у ритму, експлозивна снага) и успеха у РГ (Поповић, 1986; Miletić i sar., 1998; Miletić i sar., 2004; Douda, Avloniti, Kasabalis, \& Tokmakidis, 2007; Moskovljević i sar., 2009). Maлобројна су претходна истраживања на узорку студената, посебно мушке популације, која су дошла до различитих резултата и не дају јасну слику о повезаности моторичких способности и успешности у извођењу технике РГ (Wolf-Cvitak, 1984; Šebić-Zuhrić, Manić, Bonacin, i Hmjelovjec, 2008). Из ових разлога, у истраживању су испитиване поменуте моторичке способности, важне за успех у РГ, али на студентској популацији различитог пола.

Циљ истраживања је био да се испита повезаност постигнућа у савладавању програма РГ и моторичких способности важних за успешност у РГ, код студената Факултета спорта и физичког васпитања (ФСФВ) различитог пола. На основу горе наведених резултата претходних истраживања, који говоре о значајној повезаности гипкости, равнотеже, координације, координације у ритму и експлозивне снаге, са успешношћу у РГ као спортској грани, претпоставка је да ће се и на узорку студената ФСФВ различитог пола, појавити значајна повезаност моторичких способности и успешности у савладавању садржаја РГ. 


\section{МЕТОД}

\section{Узорак испитаника}

Истраживањем је обухваћено 58 студената друге године академских студија ФСФВ, старости 20-21 година. Према полној структури узорак је чинило 29 студената и 29 студенткиња. Овакав узорак је одабран имајућу у виду да су образовним стандардима и наставним планом за основну школу предвићени садржаји из РГ и да студенти ФСФВ, као будући професори физичког васпитања и спорта, морају овладати знањима, умењима и вештинама из РГ, без обзира на пол.

\section{Узорак варијабли и инструменти}

Процена моторичког статуса испитаника извршена ја на основу података добијених у тестовима за процену: равнотеже, координације, гипкости, експлозивне и репетитивне снаге мишића опружача ногу. Успешност у РГ је операционализована преко експертске оцене.

За процену равнотеже целог тела коришћен је тест Фламинго (Eurofit, 1993). Тест се изводи на клупици за равнотежу, стајањем на једној нози.

За процену опште координације коришћен је тест 20 искорака са палицом (Курелић, Момировић, Стојановић, Штурм, Радојевић, и Вискић, 1975). Задатак испитаника је да 20 пута правилно искорачи наизменично десном, па левом ногом и при сваком искораку провуче палицу испод ноге.

За процену координације у ритму коришћен је тест Бубњање ногама и рукама (Metikoš, Hofman, Prot, Pintar, i Oreb, 1989). Овај тест се састоји од циклуса наизменичних покрета ногу и руку за одређено време.

За процену гипкости коришћен је тест Активно подизање ноге (Božić, Pažin, Berjan, Planić, \& Ćuk, 2010). Овим тестом се процењује активна гипкост (испитаник активно подиже једну ногу док не постигне највећу амплитуду) и пасивна гипкост (мерилац додатно потискује ногу до крајње амплитуде) мишића задње ложе бута.

Репетитивна снага мишића ногу је процењеа применом теста Серија поновљених скокова у трајању $15 \mathrm{~s}$ (15sСПСкок), помоћу апарата „Optojump-kompjuterizovani sistem Bosco“" (Bosco,
\& Luhtanen, 1983). Испитаници, у оквиру задатог временског интервала, изводе што је могуће већи број максимално високих скокова, са што је могуће краћим временом контакта.

За процену експлозивне снаге мишића ногу коришћена су два теста, такође помоћу апарата „Optojump-kompjuterizovani sistem Возсо“: Вертикални скок из получучња ठез замаха руку (СкокВПЧ) (Komi, \& Bosco, 1978) и Скок увис након саскока без замаха руку (СкокВНС), којим се мери максимална висина скока и експлозивна снага.

Експертска оцена је коришћена за процену успешности у РГ. Оцењивани су састав без реквизита, састав вијачом и састав лоптом на основу видео записа. Три међународне суткиње са важећом „Brevet“ лиценцом Међународне гимнастичке федерације у ритмичкој гимнастици, оцењивале су снимљене саставе, независно једна од друге. За сваки састав, свака суткиња је давала три оцене: оцена за тачност изведеног састава, оцена за технику извођења састава и оцена за усклађеност покрета са музиком. Од ове три оцене израчуната је средња оцена за сваки састав. Након тога, израчуната је просечна оцена за сва три састава које је дао један судија. Коначна експертска оцена изведена је као средња вредност три судијске оцене. Пре него што су приступиле оцењивању испитаника, суткиње су од стране аутора истраживања биле у потпуности упознате са саставима које ће оцењивати и целокупном процедуром оцењивања. Требало би напоменути да су критеријуми оцењивања студената, на предмету Теорија и методика РГ ФСФВ, другачији од оцењивања такмичарки. Код студената се приоритет даје тачном, прецизном и складном извођењу композиција, при чему се не инсистира на великим амплитудама. Оцењивање ce, због уједначавања критеријума, вршило према Скали за процену усвојености програмских садржаја из ритмичке гимнастике (Табела 1), са истим критеријумом оцењивања према мушким и женским испитаницима, а у складу са деловима Правилника Међународне гимнастичке федерације (Правилник ритмичке гимнастике - ФИГ, 2013), који се односе на оцењивање грешака у извођењу састава и усклађености музике и покрета. Распон оцена је био од 5 до 10. 
Табела 1.Скала за процену усвојености програмских садржаја из ритмичке гимнастике

\begin{tabular}{|c|c|}
\hline Оцена & Опис (Критеријум) \\
\hline $5-5.4$ & $\begin{array}{l}\text { Састав није уопште изведен или састав је делимично изведен (само поједини елементи, неповезано), } \\
\text { са великим бројем техничких грешака у извођењу покрета телом и реквизитом, без усклађености } \\
\text { покрета са музиком. }\end{array}$ \\
\hline $5.5-5.9$ & $\begin{array}{l}\text { Мали део састава је изведен повезано, или цео састав је изведен са пуно великих грешака у техници } \\
\text { извођења покретат елом или реквизитом, без усклађености са музиком. }\end{array}$ \\
\hline $6-6.4$ & $\begin{array}{l}\text { Састав је изведен у целини повезано, са } 3-4 \text { нетачно изведена елемента, са великим и средњим } \\
\text { грешкама у техници извођења покрета телом и реквизитом, покрет је делимично неусклађен са } \\
\text { музиком (4 и више тактова). }\end{array}$ \\
\hline $6.5-6.9$ & $\begin{array}{l}\text { Састав је изведен у целини повезано, са } 1-2 \text { елемента нетачно изведена, са средњим и малим } \\
\text { грешкама у техници извођења покрета телом и реквизитом, покрет је делимично неусклађен са } \\
\text { музиком (4 и више тактова). }\end{array}$ \\
\hline $7-7.4$ & $\begin{array}{l}\text { Састав је изведен у целини тачно, уз већи број средњих и малих грешкака у извођењу током целог } \\
\text { састава, делимично неусклађено са музиком (до } 2 \text { такта). }\end{array}$ \\
\hline 7.5- 7.9 & $\begin{array}{l}\text { Састав је изведен у целини тачно, уз мањи број средњих и малих грешака извођења у појединим } \\
\text { деловима састава, делимично неусклађено са музиком (до } 2 \text { такта). }\end{array}$ \\
\hline $8-8.4$ & Састав је изведен у целини тачно, уз већи број малих грешака, усклађено са музиком. \\
\hline $8.5-8.9$ & Састав је изведен у целини тачно, са повремено мањим грешкама у извођењу, усклађено са музиком. \\
\hline $9-9.4$ & $\begin{array}{l}\text { Састав је изведен у целини тачно, са добром техником извођења покрета телом и реквизитом } \\
\text { (могућа појава малих грешака, до 5), уз присуство склада и хармоничности извођења и потпуну } \\
\text { усклађеност покрета са музиком. }\end{array}$ \\
\hline $9.5-10$ & $\begin{array}{l}\text { Састав је изведен у целини тачно, са добром техником извођења покрета телом и реквизитом } \\
\text { (могућа појава малих грешака, 1-2), уз присуство склада и хармоничности извођења и потпуну } \\
\text { усклађеност покрета са музиком. }\end{array}$ \\
\hline
\end{tabular}

\section{Ток и поступци истраживања}

Сви подаци прикупљени су након завршене наставе на предмету Теорија и методика РГ, која је трајала 12 недеља. Мерења су извршена у два дана. Првог дана процењиване су моторичке способности студената, а другог дана студенти су изводили саставе без реквизита, вијачом и лоптом, који су забележени видео камером. Исти мериоци и судије су извршили сва мерења и оцењивања.

\section{Обрада података}

Из простора дескриптивне статистике одређене су: аритметичка средина (AS), стандардна девијација (SD), минимална (MIN) и максимална вредност (MAX). За утврђивање везе између моторичких способности и експертске оцене коришћена је Пирсонова корелациона анализа (Pearson-product moment).

\section{РЕЗУЛТАТИ}

Резултати дескриптивне статистике приказани су у Табели 2. Они су показали да просечна оцена за сва три састава код испитаника мушког пола износи 7.53 ( $\mathrm{SD}=0.68)$, а код испитаника женског пола износи $7.75(\mathrm{SD}=0.81)$.

Табела 2. Дескриптивна статистика - моторичке варијабле

\begin{tabular}{lrrrrrrrrr}
\hline & \multicolumn{3}{c}{ Мушкарци (N=29) } & \multicolumn{4}{c}{ Жене (N=29) } \\
\cline { 2 - 10 } & \multicolumn{1}{c}{ AS } & \multicolumn{1}{c}{ SD } & \multicolumn{1}{c}{ MIN } & MAX & \multicolumn{1}{c}{ AS } & \multicolumn{1}{c}{ SD } & \multicolumn{1}{c}{ MIN } & MAX \\
\hline Фламинго тест & 5.45 & 4.32 & 1.00 & 17.00 & 5.55 & 3.92 & 1.00 & 14.00 \\
20 искорака са палицом & 11.64 & 1.72 & 9.22 & 15.69 & 12.54 & 1.46 & 10.42 & 15.21 \\
Бубњање ногама и рукама & 12.85 & 2.87 & 7.00 & 17.75 & 12.16 & 2.28 & 5.00 & 17.00 \\
Активно подизање леве ноге & 96.07 & 10.55 & 76.00 & 127.00 & 108.86 & 15.03 & 71.00 & 142.00 \\
Пасивно подизање леве ноге & 118.38 & 13.08 & 96.00 & 150.00 & 133.97 & 18.81 & 94.00 & 180.00 \\
Активно подизање десне ноге & 95.72 & 9.91 & 76.00 & 118.00 & 107.55 & 15.41 & 76.00 & 147.00 \\
Пасивно подизање десне ноге & 115.69 & 11.92 & 94.00 & 144.00 & 132.45 & 19.89 & 93.00 & 180.00 \\
\hline
\end{tabular}


Повезаност постигнућа у РГ и испитиваних моторичких способности код испитаника мушког и женског пола проверена је корелационом анализом (Пирсонов коефицијент корелације). Корелациона анализа између експертске оцене из РГ и испитиваних моторичких варијабли добијених на финалном мерењу, на целом узорку, показала је постојање статистички значајних корелација на тестовима 20 искорака са палицом, активно подизање леве ноге, пасивно подизање леве ноге, активно подизање десне ноге и пасивно подизање десне ноге (Табела 3). У субузорку мушких испитаника постоји и статистички значајна позитивна корелација између оцене из РГ и скора на тесту Бубњање ногама и рукама. Уколико се посматра субузорак женских испитаника корелације између оцене из РГ и тестова 20 искорака са палицом и Бубњање ногама и рукама нису статистички значајне.

Корелациона анализа између експертске оцене из РГ и резултата мерења експлозивне и репетитивне снаге мишића опружача ногу (скокови), није показала статистички значајне корелације како посматрано на целом узорку, тако и на субузорцима мушких и женских испитаника (Табела 4).

Табела 3. Пирсонови коефицијенти корелације између моторичких способности и експертске оцене РГ

\begin{tabular}{lccc}
\hline & Цео узорак & Мушкарци & Жене \\
\hline Фламинго тест & -.232 & -.339 & -.145 \\
20 искорака са палицом & $-.286^{*}$ & $-.427^{*}$ & -.271 \\
Бубњање ногама и рукама & .234 & $.398^{*}$ & .122 \\
Активно подизање леве ноге & $.320^{*}$ & .353 & .250 \\
Пасивни подизање леве ноге & $.409^{* *}$ & $.413^{*}$ & $.375^{*}$ \\
Активно подизање десне ноге & $.329^{*}$ & .302 & .299 \\
Пасивно подизање десне ноге $^{*}$ - значајност на нивоу 0.05 & ${ }^{* *}$ - Значајност на нивоу 0.01 & $.421^{*}$ \\
\hline
\end{tabular}

Табела 4. Пирсонови коефицијенти корелације између скокова и експертске оцене из РГ

\begin{tabular}{lccc}
\hline & Цео узорак & Мушкарци & Жене \\
\hline СкокВПЧ maxcm & -.002 & .213 & .121 \\
СкокВНС maxcm & -.045 & .028 & .054 \\
СкокВНС maxWkg & .106 & .069 & .244 \\
15sСПСкок maxcm & -.002 & .051 & .139 \\
15sСПСкок maxWkg & .169 & .069 & .321 \\
\hline
\end{tabular}

\section{ДИСКУСИЈА}

Корелациона анализа између експертске оцене из РГ и равнотеже, као моторичке варијабле није показала постојање статистички значајних корелација како на целом узорку, тако и на субузорцима мушких и женских испитаника. Утицај способности одржавања равнотеже није се показао статистички значајним за успешност извођења ритмичких састава, што је налаз, који је у складу са досадашњим истраживањима (Miletić i sar., 1998; Šebić-Zuhrić i sar., 2008). Разлог за то би се могао потражити у самој структури ритмичких састава, у којима су се као равнотеже појављивале најједноставније вежбе из ове структурне групе и то у минималном броју (1-2 равнотеже по саставу). Коришћени су положаји са већом површином ослонца, краћим временом трајања и једноставнијим положајем слободних делова тела и у таквом обиму нису утицали на судијску оцену, па самим тим нису дошли у везу са предикторским варијаблама.

На основу истраживања ове проблематике у спорту са такмичаркама РГ (Поповић, 1986; Санадер, 2000; Moskovljević i sar., 2009), утврђена је позитивна корелација координације и успешности у 
РГ. Резултати истраживања на студентској популацији нису показали повезаност специфичних кретања у РГ са варијаблом координација (ŠebićZuhrić i sar., 2008), што су аутори објаснили неадекватним избором тестова за процену координације. Међутим, ово истраживање је потврдило статистички значајну корелацију између опште координације и експертске оцене из РГ, посматрано на целом узорку, што значи да се утицај способности опште координације показао значајним за успешно усвајање програмских садржаја РГ. Генерални налаз, добијен на целом узорку, указује да би се поменути тест 20 искорака са палицом могао користити за процену опште координације, са студентском популацијом у настави РГ.

И општа координација и њен фактор координација у ритму су као моторичке варијабле показале статистички значајну позитивну корелацију са експертском оценом из РГ код узорка мушкараца, док код узорка жена та корелација није статистички значајна. То би се могло објаснити на следећи начин: жене већином преферирају (Gošnik, Sedar, i Bunjevac, 2007) и упражњавају у слободно време, физичке активности које су координационо сложеније и које садрже естетске компоненте (плесови, аеробик, фитнес); у односу на мушкарце, дакле, више су упућене на координационо сложена кретања са израженом естетском компонентом. У овом истраживању, мушки испитаници показују боље резултате када је у питању координација (општа и њен фактор координација у ритму) као моторичка способност и немају претходно искуство у координационо сложеним кретањима са наглашеном естетском компонентом, што оставља више простора за напредовање кроз усвајање програмских садржаја из ритмичке гимнастике.

У свим досадашњим истраживањима којима се утврђивала повезаност моторичких способности са успешношћу извођења у РГ, примењивани су тестови за процену гипкости (Поповић, 1986; Дамјановска, 1988; Дамјановска, 2000; Miletić i sar., 1998; Санадер, 2000; Бијелић, 2003; Di Cagno et al., 2009; Moskovljević i sar., 2009) као моторичке способности, за коју се у РГ каже да је „прва међу једнаким“. У овом истраживању процењивана је активна и пасивна гипкост, леве и десне ноге, код испитаника оба пола. Корелационом анализом је утврђена повезаност између експертске оцене из РГ и сва четири теста гипкости посматрано на це- лом узорку. То би значило да је гипкост изузетно значајна моторичка способност за успешно усвајање програмских садржаја ритмичке гимнастике, као и других сродних дисциплина (плес, балет), што је у складу са досадашњим истраживањима (Поповић, 1986; Дамјановска, 1988; Дамјановска, 2000; Miletić i sar., 1998; Moskovljević i sar., 2009; Vlašić, Oreb i Furjan-Mandić, 2007; Санадер, 1985; Бијелић, 2003; Сузовић и Порчић, 2012). Кад се посматра повезаност по полу, пасивна гипкост леве и десне ноге је показала статистички значајну повезаност са експертском оценом и код мушкараца и код жена. Поседовање добре пасивне гипкости је предуслов за постизање бољег резултата код активне гипкости. Садржаји РГ, које су студенти вежठали три пута недељно на часовима практичне наставе, подразумевали су вежбе обликовања, елементе скокова, равнотежа и окрета, у којима се инсистирало на амплитуди и ширини покрета.

Корелационом анализом је утврђено да не постоји статистички значајна повезаност између експертске оцене из РГ и експлозивне и репетитивне снаге мишића ногу, како на целом узорку, тако и на субузорцима мушкараца и жена, што је у супротности са неким досадашњим истраживањима (Wolf-Cvitak, 1984; Miletić i sar., 1998). Резултат истраживања указује да се ове две моторичке способности, у овом случају нису показале значајним за успешно усвајање програмских садржаја РГ. Разлог за то би можда требало тражити у чињеници да је дужина ритмичких састава, којима је вршена провера успешности, износила 16 2/4 или 3/4 тактова. Кратко трајање састава није омогућило појаву већег броја елемената из једне структурне групе (нпр.скокова), па у таквом обиму (1 скок по саставу), елементи исте структурне групе нису утицали на експертску оцену, па и веза са предикторским варијаблама није била статистички значајна.

Као ограничење овог истраживања може се навести чињеница да су као узорак испитаника узети студенти ФСФВ различитог пола, тако да резултати ове студије не могу да се генерализују на популацију која се бави РГ. Међутим у основи овог истраживања, поставило се питање да ли би се и код студената ФСФВ оба пола, утврдила повезаност значајних моторичких способности за РГ са успешношћу у РГ. Резултати истраживања потврђују чињеницу да су гипкост и координација две најважније моторичке способности за успе- 
шно усвајање програмских садржаја РГ и код студената ФСФВ. С друге стране значајна чињеница за одабир узорка је и та да би они, као будући професори спорта и физичког васпитања, требало систематски, кроз наставу физичког васпитања, да примењују базичне садржаје РГ са школском децом оба пола. При том би морали знати које се моторичке способности првенствено могу развијати помоћу садржаја РГ, а сходно узрасту деце.

\section{ЗАКЉУЧАК}

Резултати овог истраживања упућују на закључак да су, код студената ФСФВ, будућих професора физичког васпитања и спорта, за успешно савладавање програмских садржаја РГ од значаја моторичке способности, координација и гипкост, које су се издвојиле као најважније моторичке способности и у истраживањима на узорку девојчица које се активно баве РГ. Полне специфичности, у корист студената мушког пола, испољиле су се у погледу повезаности ових моторичких способности и експертске оцене, што би убудуће требало даље истраживати. Равнотежа, експлозивна и репетитивна снага мишића ногу се у овом истраживању нису издвојиле као зна-

\section{ЛИТЕРАТУРА}

1. Бијелић, С. (2003). Балеииска иррииррема у функиији развијать мотиоричких сйособностии (Необјављена докторска дисертација). Факултет физичког васпитања и спорта, Бањалука.

2. Bosco C., \& Luhtanen, P. (1983). A simple method for measurement of mechanical power in jumping. European Journal of Applied Physiology and Occupational Physiology, 50(2), 273-282.

3. Božić, P., Pažin, N., Berjan, B., Planić, N., \& Ćuk, I. (2010). Evaluation of the Field Tests of Flexibility of the Lower Extremity: Reliability and the Concurrent and Factorial Validity. Journal of Strength and Conditioning Research, 24(9), 2523-2531.

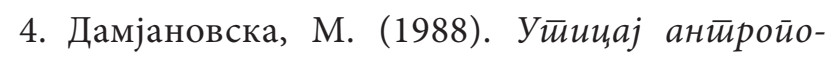
метиријских и биомоторочиких варијабли и моїућносиии йреgвиђаюа усиееха у ритимичко-сйорйској йимнастиици (Необјављена ма- чајан фактор успешности у савладавању садржаја РГ, тј. ове моторичке способности нису показале значајну повезаност са експертском оценом из РГ. У наредним истраживањима требало би усмерити пажњу на усложњавање равнотежних положаја и повећање њиховог броја, као и броја скокова у ритмичким саставима у физичком вежбању школске популације и студената ФСФВ, као и на проналажење адекватних моторичких тестова који ће на специфичнији начин мерити способност одржавања равнотежног положаја и способност експлозивне и репетитивне снаге мишића ногу у ритмичкој гимнастици.

У даљим истраживањима требало би проверити моторичке факторе успешности усвајања ритмичке гимнастике на већем узорку студената ФСФВ, затим ученика основних школа, применом програма ритмичке гимнастике и увођењем специфичних тестова за мерење моторичких способности значајних за успешност у ритмичкој гимнастици.

Рад је део пројекта "Ефекти примењене физичке активности на локомоторни, метаболички, психосоцијални и васпитни статус популације Републике Србије” (бр.III47015).

гистарска теза). Факултет физичке културе, Београд.

5. Дамјановска, М. (2000). Ефекӣи оgређеноі ироірама рииммичко-сйорйске іимнасиичке на тирансбормацију оgређених морфолошких ка-

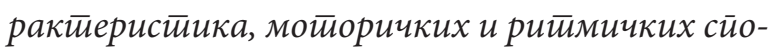
собносиии ученица 4. разреgа основне школе у Скойљу (Необјављена докторска дисертација). Факултет за физичку културу, Скопље.

6. Di Cagno, A., Baldari, C., Battaglia, C., Brasili, P., Merni, F., Piazza, M., Toselli, S., Ventrella, A.R., \& Guidetti, L. (2008). Leaping ability and body composition in rhythmic gymnasts for talent identification. Journal of Sports Medicine and Physical Fitness, 48, 341-346.

7. Di Cagno, A., Baldari, C., Battaglia, C., Monteiro, M.D., Pappalardo, A., Piazza, M., \& Guidetti, L. 
(2009). Factors influencing performance of competitive and amateur rhythmic gymnastics - Gender differences. Journal of Science and Medicine in Sport, 12, 411-416.

8. Douda, H., Avloniti, A., Kasabalis, A., \& Tokmakidis, S. (2007). Adaptations on Physical Performance Characteristics after a 6-month specific training in rhythmic gymnasts. Medical Problems of Performing Artistis, 22, 10-17.

9. Eurofit (1993). Eurofit Tests of Physical Fitness. 2nd Edition. Strasbourg.

10. Gošnik, J., Sedar, M., \& Bunjevac, T. (2007). Preferencije studenata/ica Filozofskog fakulteta u Zagrebu prema sportskim aktivnostima. 16. Ljetna škola kineziologa Republike Hrvatske.

11. Исмаил, А.Х. (1976). Интегрирани развој: Теорија и експериментални резултати. Кинезиоroīuja, 6(1-2), 7-28.

12. Јаковљевић С., Каралејић, М., и Радовановић, И. (2007). Релације између два начина оцењивања актуелног индивидуалног квалитета кошаркаша као критеријума њихове успешности. Физичка кулитура, 61(1-2), 25-33.

13. Јевтић, Б., Радојевић, Ј., Јухас, И., и Ропрет, Р. (2011). Дечији сйорӣ оg йраксе gо акаяемске областии. Београд: Факултет спорта и физичког васпитања.

14. Каралејић, М., и Јаковљевић, С. (2008). Теорија и метиоgика комарке. Београд: Факултет спорта и физичког васпитања.

15. Карпенко, Л.А. (2003). Художесиивенная іимнастиика. Санкт-Петербург: Государственная Академия физической культуры имени П.Ф.Лесгафта.

16. Касум, Г. (2001). Утицај морфолошких и моторичких карактеристика студената ФФК у Београду на ефикасност савладавања програма из рвања. Физичка кулитура, 55(1-4), 42-48.

17. Komi, P.V., \& Bosco, C. (1978). Utilization of stored elastic enery in leg extensor muscles by men and women. Medicine \& Science in Sports \& Exercise, 10, 261-265.

18. Курелић, Н., Момировић, К., Стојановић, М., Штурм, Ј., Радојевић, Ђ., и Вискић, Н. (1975).

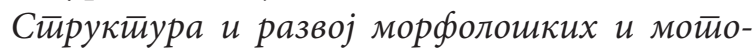
ричких gимензија омлаgине. Београд: Инсти- тут за научна истраживања Факултета за физичко васпитање.

19. Metikoš, D., Hofman, E., Prot, F., Pintar, Ž., i Oreb, G. (1989). Mjerenje bazičnih motoričkih dimenzija sportaša. Zagreb: Fakultet za fizičku kulturu.

20. Miletić, Đ., Srhoj, Lj., i Bonacin, D. (1998). Utjecaj inicijalnog statusa motoričkih sposobnosti na učenje motoričkih znanja u ritmičko-sportskoj gimnastici. Kineziologija, 30(2), 66-75.

21. Miletić, Đ., Sekulić, D., \& Wolf-Cvitak, J. (2004). The leaping performance of 7-year-old novice rhythmic gymnasts is highly influenced by the condition of their motor abilities. Kinesiology, $36(1), 35-43$.

22. Moskovljević, L., Radisavljević, L., \& Dabović, M. (2009). Relation Beetween Motor Abilities and aperforming of Fundamental Elements in Rhythmic Gymnastics. FISU Conference 25 thUniversiade "The role of University sports in education and society - a platform for change", Proceedin$g s$, (pp. 196-204). Belgrade: Faculty of sport and physical education,

23. Московљевић, Л., и Орлић, А. (2012). Релације између способности и ставова студената и успешности у ритмичкој гимнастици - полне специфичности. Физичка кулитура, 66(2), 129-137.

24. Недељковић, А. (2007). Уйииај йелесних gимензија на исйољавағе максималне снайе мишића. (Необјављена докторска дисертација). Факултет спорта и физичког васпитања, Београд.

25. Поповић, Р. (1986). Значај морфолочких карактиеристика, мотиоричких димензија, музикалностии и неких конатиивних особина личносиии за усиеех у ритимичкој іимнастиици (Необјављена gокторска дисертација). Факултет за физичку културу, Београд.

26. Поповић, Б. (2010). Утицај морфолошких и моторичких карактеристика студената ФФК у Београду на ефикасност савладавања програма наставе из џудоа. Физичка кулитура, 64(1), 62-71.

27. Правилник ритмичке гимнастике ФИГ (2013). Међународна гимнастичка федерација - ФИГ, Технички комитет за ритмичку гимнастику ФИГ (превод). Гимнастички савез Србије, Савез за ритмичку гимнастику Србије. 
28. Радисављевић, Л., и Московљевић, Л. (2011). Основе ритмике. У Б. Јевтић, Ј. Радојевић, И. Јухас и Р. Ропрет (ур.), Дечији сйорй - og ираксе gо акаяемске области, (стр. 395-409). Београд: ФСФВ.

29. Санадер, А. (1985). Утичияај вежби класичної балети а на ефикасности савлађивана основне

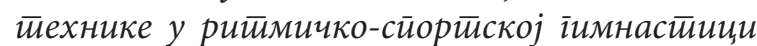
(Необјављени дипломски рад). Факултет физичке културе Универзитет у Београду.

30. Санадер, А. (2000). Моделне каракиеиеристике јуіословенских сениорки у риитмичкој іимнастиици (Необјављена магистарска теза). Факултет физичке културе, Београд.

31. Сузовић, Д., и Порчић, Б. (2012). Утицај морфолошких карактеристика и моторичких способности на селекцију у балету. Физичка куліичра, 66(1), 32-39.
32. Šebić Zuhrić, L., Manić, G., Bonacin, D., i Hmjelovjec, I. (2008). Relacije bazično motoričkih sposobnosti i stilizovanih kretnih struktura u muškoj ritmičkoj gimnastici. Homo Sporticus, 1, 18-21.

33. Вишњић, Д., Јовановић, А., и Милетић, К. (2004). Теорија и метиоgика физичкої васиичйана. Београд: СИА.

34. Vlašić, J., Oreb, G., / Furjan-Mandić, G. (2007). Povezanost motoričkih i morfoloških obilježja studentica s uspješnosti u narodnim plesovima. Kineziologija ,39(1), 49-61.

35. Wolf-Cvitak, J. (1984). Relacije između morfoloških i primarnih motoričkih dimenzija sa uspješnosti u ritmičko sportskoj gimnastici kod selekcioniranog uzorka ispitanika (Neobjavljena magistarska teza). Fakultet za fizičku kulturu, Zagreb.

\title{
RELATIONEN EINIGER MOTORISCHER FÄHIGKEITEN UND DES ERFOLGS IN RHYTHMISCHER GYMNASTIK BEI STUDENTEN UNTERSCHIEDLICHEN GESCHLECHTS
}

\begin{abstract}
Zusammenfassung:
Ziel der Untersuchung war es, bei Studenten unterschiedlichen Geschlechts die Verbindung zwischen Bewältigung eines Rhythmikgymnastik-Programms (RG) und der motorischen Fähigkeiten festzustellen, die für den Erfolg in dieser Sportdisziplin bedeutend sind. Die Untersuchung umfasste 58 StudentInnen der Fakultät für Sport und Sportunterricht (29 Studenten und 29 Studentinnen im Alter von 20-21 Jahren). Gleichgewicht wurde mit Hilfe des „Flamingo“-Tests gemessen; allgemeine Koordinierung mit Hilfe eines Tests mit 20 Schritten mit Turnkeule; Rhythmuskoordinierung mit Hilfe von Trommeln mit Beinen und Armen; Geschmeidigkeit wurde mit dem Test der aktiven Beinhebung gemessen; explosive Muskelkraft der Beinstrecker mit Hilfe eines Vertikalsprungs aus der Halbhocke und eines Strecksprungs; die Wiederholungskraft der Muskeln der Beinstrecker mit Hilfe einer Serie wiederholter Sprünge in der Dauer von 15 Sekunden. Der Erfolg in Rhythmikgymnastik-Programm wurde durch eine Experteneinschätzung operationalisiert. Für die Feststellung der Relationen zwischen den motorischen Fähigkeiten und der Experteneinschätzung wurde die Pearson-product moment Analyse verwendet. Die Ergebnisse dieser Untersuchung weisen auf die Schlussfolgerung hin, dass bei den StudentInnen der Fakultät für Sport und Sportunterricht für eine erfolgreiche Bewältigung der Inhalte eines Rhythmikgymnastik-Programms motorische Fähigkeiten, Koordinierung und Geschmeidigkeit bedeutend sind.
\end{abstract}

Schlüsselwörter: GESCHMEIDIGKEIT / KOORDINIERUNG / BEWERTUNG / SPORTUNTERRICHT / SPORT

Примљен: 05.07.2016.

Прихваћен: 02.11.2016.

(c) 2016 Autor. Objavio Fizička kultura (www.fizickakultura.com). Ovo je članak otvorenog pristupa i distribuira se u skladu sa Creative Commons licencom (http://creativecommons.org/licenses/by/3.0/rs/). 